\title{
Attenuation by Divalent Cations of the Effect of the Phytoalexin Rishitin on Erwinia carotovora var. atroseptica
}

\author{
By G. D. LYON \\ Scottish Horticultural Research Institute, Invergowrie, \\ Dundee DD2 5DA, Scotland
}

(Received 4 May 1978)

\begin{abstract}
Rishitin at $300 \mu \mathrm{g} \mathrm{ml}^{-1}$ rapidly decreased oxygen uptake by Erwinia carotovora var. atroseptica suspended in $0.1 \%(\mathrm{w} / \mathrm{v})$ peptone water. Variation in the composition of the suspending medium affected sensitivity to rishitin, with $\mathrm{Mg}^{2+}$ and, to a lesser extent, $\mathrm{Ca}^{2+}$ decreasing bacterial sensitivity. Addition of $100 \mu \mathrm{g}$ rishitin $\mathrm{ml}^{-1}$ affected cell membrane permeability causing an increase in conductivity of the suspending medium. Inhibition of oxygen uptake by the cationic surfactant hyamine 2389 or by sodium lauryl sulphate was also alleviated by the addition of $\mathrm{Mg}^{2+}$ suggesting that rishitin may act directly on cell membranes of bacteria, possibly in a manner similar to a cationic surfactant or a membraneactive antibiotic. The results also suggest that the sensitivity of E. atroseptica to rishitin in potato tubers may be affected by variation in their $\mathrm{Mg}^{2+}$. or $\mathrm{Ca}^{2+}$ content. Phaseollin did not inhibit respiration of E. atroseptica.
\end{abstract}

\section{INTRODUCTION}

Potato tubers incubated in air and therefore resistant to rotting produce the phytoalexin rishitin when inoculated with the Gram-negative soft rot bacterium Erwinia carotovora var. atroseptica ( $E$. atroseptica). Tubers incubated under low oxygen conditions, and consequently more susceptible to rotting, produce little or no rishitin (Lyon, 1972a,b). These observations, together with the demonstration that rishitin affects the viability of $E$. atroseptica in vitro (Lyon \& Bayliss, 1975), led to the conclusion that rishitin may play a role in the resistance of tubers to E. atroseptica.

Lyon \& Bayliss (1975) demonstrated a difference in the sensitivity to rishitin of $E$. atroseptica when bacteria were incubated in two different media, viz. $0.1 \%(\mathrm{w} / \mathrm{v})$ peptone water and a defined growth medium (GA). The present work was initiated to determine which constituent(s) of the defined medium GA affected this difference and so to suggest a possible mode of action of rishitin. The effect of treatments on the sensitivity of $E$. atroseptica to rishitin was assessed by measuring decreases in oxygen uptake as an indicator of physiological damage.

\section{METHODS}

Bacteria. Erwinia carotovora var. atroseptica isolate 17, obtained by M. C. M. Pérombelon at this Institute from potato stem tissue showing blackleg symptoms, was grown at $23^{\circ} \mathrm{C}$ in shaken cultures of nutrient broth [containing $\left(\mathrm{g} \mathrm{l}^{-1}\right)$ : beef extract, 1; yeast extract, 2; Bacto-peptone, 5; $\mathrm{NaCl}, 5 ; \mathrm{pH} \mathrm{7} 4$ ]. Cultures $(24 \mathrm{~h})$ were centrifuged and washed twice with $0.1 \%(\mathrm{w} / \mathrm{v})$ peptone water $\mathrm{pH} 7.0$ (Lyon \& Bayliss, 1975) before being resuspended in peptone water for respiration experiments. For conductivity experiments, cultures were washed twice with, and then resuspended in, $0 \cdot 3 \mathrm{M}$-sucrose.

Phytoalexins. Chromatographically pure rishitin was extracted from potato tubers inoculated with $E$. atroseptica using the method described by Lyon (1972a). Crystalline phaseollin was extracted from Phaseolus vulgaris pods treated with $3 \mathrm{~mm}-\mathrm{CuCl}_{2}$ using methods described by Bailey \& Burden (1973). 


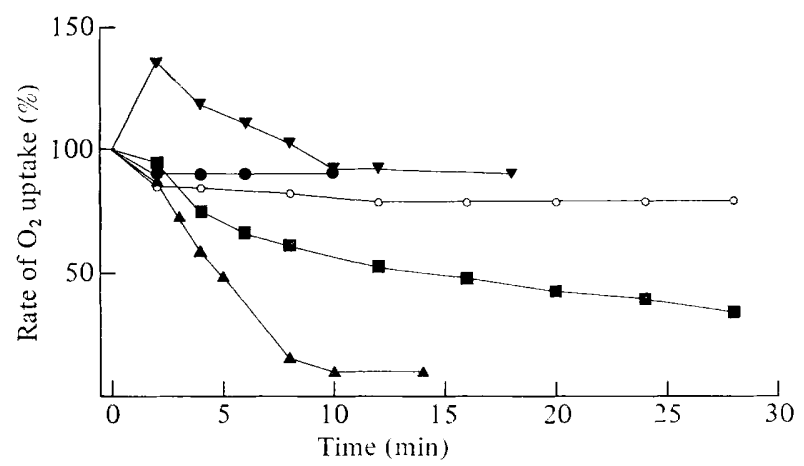

Fig. 1. Oxygen uptake by a $1 \mathrm{ml}$ suspension of E. atroseptica in $0 \cdot 1 \%$ peptone water after addition of: $\bigcirc, 100 \mu \mathrm{g}$ rishitin; $\mathbf{\square}, 200 \mu \mathrm{g}$ rishitin; $\boldsymbol{\Delta}, 300 \mu \mathrm{g}$ rishitin; $\boldsymbol{\nabla}, 300 \mu \mathrm{g}$ phaseollin; $\boldsymbol{O}, 30 \mu \mathrm{l}$ ethanol. Rishitin and phaseollin were added as ethanolic solutions $\left(10 \mathrm{mg} \mathrm{ml}^{-1}\right)$. Oxygen uptake is expressed as a percentage of the initial rate, before addition of phytoalexin.

Oxygen uptake. Measurements were made at $25^{\circ} \mathrm{C}$ using an oxygen electrode (Rank Bros, Cambridge). The concentration of bacteria was adjusted so that the addition of $5 \mu \mathrm{l}$ bacterial suspension to $1 \mathrm{ml}$ medium gave a rate of oxygen uptake of approximately $6.5 \mathrm{nmol} \mathrm{min}{ }^{-1}$ (approximately $3 \times 10^{8}$ bacteria $\mathrm{ml}^{-1}$ in peptone water). Calculations were based on the assumption that air-saturated water contained $260 \mathrm{nmol} \mathrm{O}_{2}$ $\mathrm{ml}^{-1}$ at $25^{\circ} \mathrm{C}$ (Estabrook, 1967). After $5 \mathrm{~min}$, when a steady rate of oxygen uptake was attained (initial rate), test compounds were injected into the cell and changes in oxygen uptake were continuously recorded, the rates being expressed as a percentage of the initial rate. The phytoalexins were added as ethanolic solutions $\left(10 \mathrm{mg} \mathrm{ml}^{-1}\right)$ as required.

Conductivity measurements. The conductivity of a $9 \mathrm{ml}$ suspension of approximately $10^{9}$ cells $\mathrm{ml}^{-1}$ in $0 \cdot 3 \mathrm{M}$-sucrose solution was measured using an Electronic Switchgear (London) type MC1 conductivity measuring bridge with cell type $\mathrm{CB} / 10$.

\section{RESULTS}

\section{Effect of rishitin and phaseollin on respiration}

Rishitin at $300 \mu \mathrm{g} \mathrm{ml}^{-1}$ rapidly inhibited oxygen uptake by E. atroseptica in $0 \cdot 1 \%$ peptone water and slightly reduced the rate at $100 \mu \mathrm{g} \mathrm{ml}^{-1}$ (Fig. 1). The effect of rishitin over incubation periods longer than $30 \mathrm{~min}$ was not studied. Phaseollin did not inhibit oxygen uptake but caused an immediate temporary increase followed by a return to a rate similar to that of the control [3\% $(\mathrm{v} / \mathrm{v})$ ethanol].

Variation in the composition of the medium in which the bacteria were resuspended affected their sensitivity to rishitin (Fig. 2). The rate of oxygen uptake by bacteria suspended in $0.1 \%$ peptone water was affected more than that of suspensions in a mixture of $\mathrm{KH}_{2} \mathrm{PO}_{4}$, $\mathrm{NH}_{4} \mathrm{Cl}$ and $\mathrm{MgSO}_{4}$ [the salts used by Lyon \& Bayliss (1975) in their defined medium GA]. The addition to $0.1 \%$ peptone water of $0.81 \mathrm{mM}^{-\mathrm{MgSO}_{4}}$ slightly increased the ability of the bacteria to tolerate the rishitin (Fig. 2) and the protective action of a higher concentration $(2 \cdot 0 \mathrm{~mm})$ against $200 \mu \mathrm{g}$ rishitin $\mathrm{ml}^{-1}$ is shown in Fig. 3. Equimolar concentrations of $\mathrm{Na}_{2} \mathrm{SO}_{4}$ and $\mathrm{CaSO}_{4}$ were also tested for their protective ability. The results show that the cation was the active principle and that $\mathrm{Mg}^{2+}$ was more effective than $\mathrm{Ca}^{2+}$ in conferring tolerance. Measurements of the effects on respiration of rishitin at a range of concentrations showed that, after $20 \mathrm{~min}, 50 \%$ inhibition occurred with $175 \mu \mathrm{g}$ rishitin $\mathrm{ml}^{-1}$ in the absence of $\mathrm{Mg}^{2+}$ whereas $271 \mu \mathrm{g}$ rishitin $\mathrm{ml}^{-1}$ was required to cause $50 \%$ inhibition in the presence of $2.0 \mathrm{~mm}-\mathrm{Mg}^{2+}$.

\section{Effect of surfactants on respiration}

An anionic surfactant, Triton GR-5 [60\% dioctyl sodium sulphosuccinate in propan-2ol/water $(1: 1, \mathrm{v} / \mathrm{v})]$, and a non-ionic surfactant, Triton X-100 (iso-octylphenoxypolyethoxyethanol), did not affect oxygen uptake at final concentrations of $0 \cdot 1 \%(v / v)$. However, 


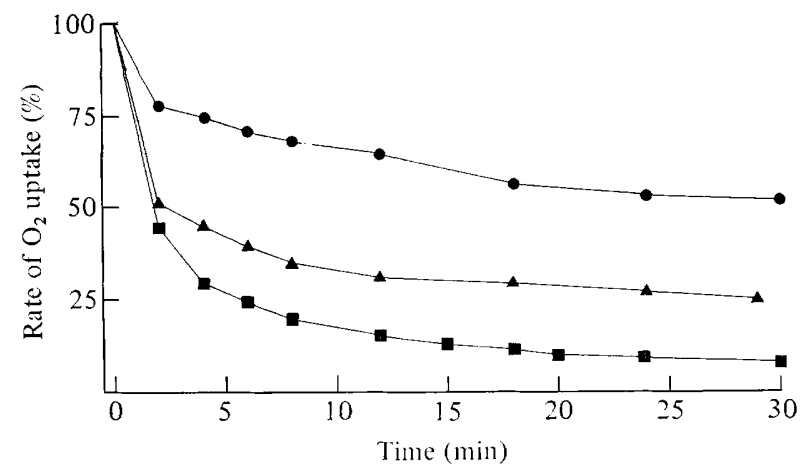

Fig. 2. Effect of $300 \mu \mathrm{g}$ rishitin $\mathrm{ml}^{-1}$ on oxygen uptake by $E$. atroseptica suspended in: solution as in defined medium GA [Lyon \& Bayliss, 1975; containing $\left(\mathrm{g} \mathrm{l}^{-1}\right): \mathrm{KH}_{2} \mathrm{PO}_{4}, 2 ; \mathrm{NH}_{4} \mathrm{Cl}$, $\left.1 ; \mathrm{MgSO}_{4} .7 \mathrm{H}_{2} \mathrm{O}, 0.2 ; \mathrm{pH} 7.0\right] ; \mathbf{C}, 0.1 \%$ peptone water $\mathrm{pH} 7.15 ; \boldsymbol{\Lambda}, 0.1 \%$ peptone water plus $0.81 \mathrm{~mm}^{-\mathrm{MgSO}_{4}}$. Oxygen uptake is expressed as a percentage of the initial rate, before addition of rishitin (as a $10 \mathrm{mg} \mathrm{ml}^{-1}$ ethanolic solution).

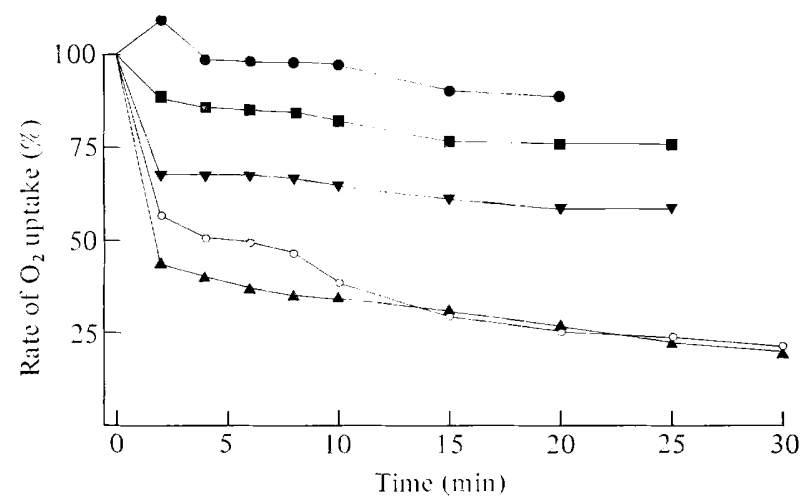

Fig. 3. Effect of divalent cations on the sensitivity of E. atroseptica to rishitin. Oxygen uptake (percentage of the initial rate) was determined after addition of $200 \mu \mathrm{g}$ rishitin $\mathrm{ml}^{-1}$ to E. atroseptica suspended in: $0,0.1 \%$ peptone water; $\boldsymbol{\square}, 0.1 \%$ peptone water plus $2 \mathrm{~mm}-\mathrm{MgSO}_{4} ; \boldsymbol{\Delta}$, $0 \cdot 1 \%$ peptone water plus $2 \mathrm{~mm}-\mathrm{Na}_{2} \mathrm{SO}_{4} ; \boldsymbol{\nabla}, 0 \cdot 1 \%$ peptone water plus $2 \mathrm{~mm}-\mathrm{CaSO}_{4}$; or $\bigcirc$, after addition of $20 \mu \mathrm{l}$ ethanol to bacterial suspension in $0.1 \%$ peptone water.

the cationic surfactant Hyamine 2389 (50\% methyldodecylbenzyltrimethylammonium chloride and methyldodecylxylylenebistrimethylammonium chloride in water) did inhibit oxygen uptake by $E$. atroseptica resuspended in peptone water, and, as with rishitin, this effect was alleviated by the addition of $\mathrm{Mg}^{2+}$. In peptone water, $17 \cdot 5$. (S.E.M. $\left.1 \cdot 8\right) \mu \mathrm{g}$ Hyamine $2389 \mathrm{ml}^{-1}$ caused a $50 \%$ inhibition of respiration after $15 \mathrm{~min}$ whereas $51 \cdot 0$ (S.E.M. 4.4 ) $\mu \mathrm{g}$ $\mathrm{ml}^{-1}$ was required to cause $50 \%$ inhibition following the addition of $2 \cdot 0 \mathrm{mM} \cdot \mathrm{Mg}^{2+}$.

Addition of sodium lauryl sulphate to $E$. atroseptica in peptone water also inhibited respiration, again to a lesser extent in the presence of $\mathrm{Mg}^{2+}$ (Fig. 4).

\section{Effect of cyanide on respiration}

Oxygen uptake was completely inhibited $20 \mathrm{~min}$ after adding $10 \mu 110 \mathrm{~mm}-\mathrm{NaCN}$ to a $1 \mathrm{ml}$ suspension of $E$. atroseptica, although the bacteria remained viable and motile.

\section{Conductivity}

Addition of $100 \mu \mathrm{g}$ rishitin $\mathrm{ml}^{-1}$ to E. atroseptica in $0.3 \mathrm{M}$-sucrose caused an increase in conductivity (Fig. 5). Hyamine 2389 at $50 \mu \mathrm{g} \mathrm{ml}^{-1}$ caused a more rapid loss of electro- 
G. D. LYON

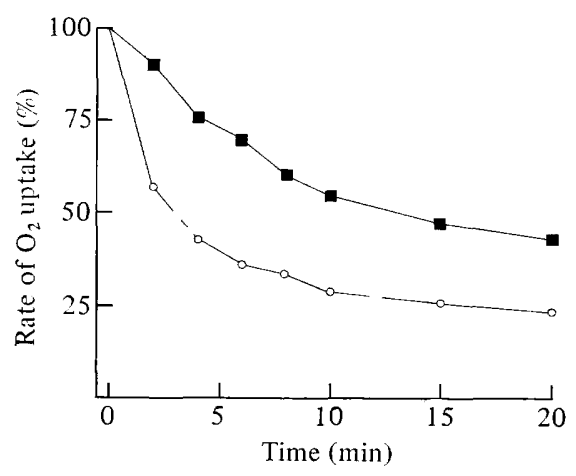

Fig. 4. Effect of addition of $20 \mu 15 \%$ sodium lauryl sulphate on oxygen uptake by $E$. atroseptica suspended in $1 \mathrm{ml} 0.1 \%$ peptone water $(O)$ or $0.1 \%$ peptone water plus $2 \mathrm{mM}_{-\mathrm{MgSO}_{4}}(\boldsymbol{\square})$.

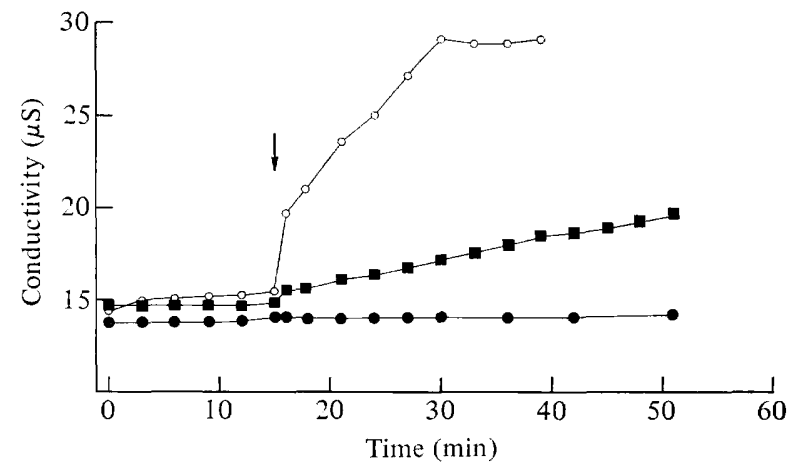

Fig. 5. Conductivity of a $9 \mathrm{ml}$ suspension of approx. $10^{9}$ E. atroseptica $\mathrm{ml}^{-1}$ in $0.3 \mathrm{M}$-sucrose before and after the addition at $15 \mathrm{~min}$ (arrowed) of :, $100 \mu \mathrm{g}$ rishitin $\mathrm{ml}^{-1}$ (added as a $10 \mathrm{mg} \mathrm{ml}^{-1}$ ethanolic solution); $\bigcirc, 50 \mu \mathrm{g}$ Hyamine $2389 \mathrm{ml}^{-1}$ (added as a $10 \%, \mathrm{v} / \mathrm{v}$, aqueous solution); $\bigcirc, 10 \mu \mathrm{l}$ ethanol $\mathrm{ml}^{-1}$.

lytes; this reached a maximum after $15 \mathrm{~min}$ when all cells had lysed. In the absence of bacteria the same amount of Hyamine increased the conductivity of the medium by $4 \cdot 15 \mu \mathrm{S}$.

\section{DISCUSSION}

The biological activity of rishitin assessed as inhibition of $\mathrm{O}_{2}$ uptake agreed with data published by Lyon \& Bayliss (1975) which showed that at $360 \mu \mathrm{g} \mathrm{ml}^{-1}$ rishitin caused complete loss of viability and at $106 \mu \mathrm{g} \mathrm{ml}^{-1}$, a $50 \%$ reduction after $4 \mathrm{~h}$. The inability of phaseollin to inhibit respiration of E. atroseptica confirmed the report by Stholasuta et al. (1971) that, unlike rishitin, it does not affect bacterial viability.

Inhibition of respiration of Escherichia coli by polymyxin B is thought to reflect either membrane damage resulting in the efflux of metabolites used for reducing potential in electron transport, or disorganization of the electron-transport chain (Storm et al., 1977). Divalent cations such as $\mathrm{Mg}^{2+}$ and $\mathrm{Ca}^{2+}$ affect the activity of polymyxin $\mathrm{B}$ (Newton, 1953, 1955) possibly by competing for negatively charged phosphate groups on membrane lipids. The detergents sodium lauryl sulphate (Reynolds, 1973) and compounds related to Hyamine 2389 (Gilby \& Few, 1960) act directly on cell membranes and the protective action of $\mathrm{Mg}^{2+}$ against another surfactant, Triton X-100, has also been reported (Unemoto \& Macleod, 1975). Rishitin also, directly or indirectly, affected membrane permeability of E. atroseptica causing an increase in the conductivity of the suspending medium. That the action of 
rishitin on E. atroseptica was also alleviated by the presence of $\mathrm{Mg}^{2+}$, and to a lesser extent by $\mathrm{Ca}^{2+}$, suggests that its mode of action may well be similar to the detergents used in these experiments or to a membrane-active antibiotic such as polymyxin. The site of action of rishitin is still uncertain but the results could be explained in terms of a disorganization of the cell membrane which controls the osmotic equilibrium of the cell As bacterial respiration requires an intact sealed cytoplasmic membrane (Simoni \& Postma, 1975), any damage to membrane function would also affect respiration. The divalent cations may be acting by 'stabilizing' the membrane and decreasing its affinity for rishitin, but it is also possible that they affect the permeability of the membrane to rishitin and hence decrease uptake, the site of action being internal to the membrane.

That the sensitivity of E. atroseptica to rishitin is reduced by the addition of $0.1 \%$ glucose to peptone water (Lyon \& Bayliss, 1975) suggests that there is an active energyrequiring mechanism, possibly involving either membrane synthesis, which is able to repair damage done by rishitin, or an active exclusion of the phytoalexin.

Unlike the other treatments, where cell death and inhibition of $\mathrm{O}_{2}$ uptake were coincident, the inhibition of $\mathrm{O}_{2}$ uptake by cyanide did not affect cell viability, thus excluding the unlikely possibility that rishitin acts at the same site as cyanide.

Not only do these results provide evidence for a possible site of action for rishitin but they also demonstrate that sensitivity of $E$. atroseptica to rishitin can be affected by alterations in the composition of the suspending medium. Lyon (1977) suggested that because the sensitivity of $E$. atroseptica to rishitin was affected by glucose concentration and medium $\mathrm{pH}$ in vitro then it was possible that variation in potato tuber composition could affect the resistance of E. atroseptica to rishitin in vivo and hence resistance to rotting. The demonstration that the sensitivity of $E$. atroseptica to rishitin is also affected by $\mathrm{Mg}^{2+}$ and $\mathrm{Ca}^{2+}$ concentration in vitro suggests that these factors may also play a role in resistance to rotting. Certainly the contents of $\mathrm{Ca}^{2+}$ and $\mathrm{Mg}^{2+}$ in potato tubers are in a range similar to those used in the present experiments. They also vary considerably [10 to 130 and 46 to $217 \mathrm{mg}$ (100 g dry matter) ${ }^{-1}$ respectively (Burton, 1966)] although no relationship has yet been shown between such variations and tuber susceptibility to rotting.

I am grateful to J. Cowan for statistical advice.

\section{REFERENCES}

Bailey, J. A. \& Burden, R. S. (1973). Biochemical changes and phytoalexin accumulation in Phaseolus vulgaris following cellular browning caused by tobacco necrosis virus. Physiological Plant Pathology 3, 171-177.

Burton, W. G. (1966). The Potato. Wageningen: Veenman \& Zonen.

EsTABROOK, R. W. (1967). Mitochondrial respiratory control and the polarographic measurement of ADP:O ratios. Methods in Enzymology 10, 41-47.

Gilby, A. R. \& Few, A. V. (1960). Lysis of protoplasts of Micrococcus lysodeikticus by ionic detergents. Journal of General Microbiology 23, 19-26.

LYON, G. D. (1972a). Occurrence of rishitin and phytuberin in potato tubers inoculated with Erwinia carotovora var. atroseptica. Physiological Plant Pathology 2, 411-416.

LyoN, G. D. (1972b). Some biochemical changes in potato tubers inoculated with Erwinia carotovora var. atroseptica. In 5th Triennial Conference of the European Association for Potato Research, Proceedings, pp. 143-144. London: Leagrave Press.
LYON, G. D. (1977). Rishitin and phytuberin in relation to bacterial soft rots of potato tubers. Annals of Applied Biology 85, 166 (abstract).

LyoN, G. D. \& BAYLiss, C. E. (1975). The effect of rishitin on Erwinia carotovora var. atroseptica and other bacteria. Physiological Plant Pathology 6, 177-186.

Newton, B. A. (1953). Reversal of the antibacterial activity of polymyxin by divalent cations. Nature, London 172, 160-161.

Newton, B. A. (1955). A fluorescent derivative of polymyxin: its preparation and use in studying the site of action of the antibiotic. Journal of General Microbiology 12, 226-236.

REYNOLDS, P. E. (1973). The bacterial cell: major structures. In Biochemistry of Bacterial Growth, pp. 63-136. Edited by J. Mandelstam \& K. McQuillen. Oxford: Blackwell Scientific Publications.

Simoni, R. D. \& Postma, P. W. (1975). The energetics of bacterial active transport. Annual Review of Biochemistry 44, 523-554.

Stholasuta, P., Bailey, J. A., Severin, V. \& DeVerall, B. J. (1971). Effect of bacterial 
inoculation of bean and pea leaves on the accumulation of phaseollin and pisatin. Physiological Plant Pathology 1, 177-183.

Storm, D. R., Rosenthal, K.S. \& Swanson, P. E. (1977). Polymyxin and related peptide antibiotics. Annual Review of Biochemistry 46, 723-763.
Unemoto, T. \& Macleod, R. A. (1975). Capacity of the outer membrane of a gram-negative marine bacterium in the presence of cations to prevent lysis by Triton X-100. Journal of Bacterio$\log y$ 121, 800-806. 